\title{
Study on Behaviour of Hybrid Fibre Reinforced Cementitious Composites
}

\author{
Meena J1, Uma Nambi J² \\ 1PG student, ${ }^{2}$ Head of the Department \\ 1,2Civil Engineering Department, Paavai Engineering College, Namakkal, Tamil Nadu, India
}

\begin{abstract}
This paper highlights the material properties of the Bendable concrete for the effective development of new structures and maintenance of existing structures. The material researchers have conducted a lot of experiments based on sustainability, durability and safety point of view. As a result of the attempts, finally a new material was established in the last decade. The proper selection of the fibre, mixing of the composite exhibit strain hardening and multiple cracking behaviour of the material. The strain hardening behaviour of the Bendable concrete gives significant advantage under flexural loading. The crack width developed under loading is very small when compared with conventional concrete due to the bridging effect of the fibre. The material properties of Bendable concrete reinforced with following $0.5 \%, 1.0 \%, 1.5 \%, 2 \%$ of steel fibre and $0.1 \%, 0.15 \%, 0.2 \%$, $0.25 \%$ of polypropylene fibre. The optimum strength attained at $1.0 \%$ of steel fibre and $0.1 \%$ of polypropylene fibre and has been claimed to be the most promising proportion of the fibre content. A series of experiments were carried out to determine the compressive strength, tensile strength and flexural characteristics of Bendable concrete.
\end{abstract}

Keywords: Bendable concrete, Sustainability, Strain hardening, Bridging

\section{INTRODUCTION}

\subsection{GENERAL}

Concrete is most widely used material for the construction. In ancient time itself the people started to use concrete for the construction because of its brittleness and compressive strength. Cement act as a binding material in the concrete to tide the aggregate. Unfortunately the production of cement consumes more amounts of natural resources and liberate large amount of $\mathrm{CO}_{2}$ which affect environmental system. So the development of new construction material is essential.

Now a day, the concrete construction industry faces lot of problem due to availability of material and bad environmental conditions. Due to this bad effect, cracks and strength losses occurr in the construction. The concrete which is mainly strong in compression but weak in tension, is also a part of load profile. To avoid the over consumption of natural resources, supplementary cementitious materials such as fly ash, rice husk ash, silica fume are used for the structure.

Recently, construction industry introduced fibres also in the concrete to provide were strength and performance based on the brittleness and ductility behaviour. Since 2003, the new construction material "Engineered cementitious composites" is developed by Victor C. Li.

Engineered cementitious composites (ECC) is a cement based material containing a mix of cement, supplementary cementitious material, sand, water and chemical admixtures, reinforced randomly distributed fibres. ECC material can improve the tensile strength, ultimate strain capacity and large strain hardening properties than conventional concrete.

The ECC can resist large load by the crack bridging properties in the failure mode of structure. This material is also used for repairing and maintenance work also. This paper illustrates potential effect of application of ECC in the construction industry.

\subsection{DEFINITION}

Engineered cementitious composite is "a special type of high performance fibre reinforced concrete containing small amount of short random fibres micromechanically designed to achieve high damage tolerance under severe loading conditions and high durability under normal service conditions".

Engineered cementitious composite (ECC) is a cement based material containing a mix of cement, supplementary cementitious material, sand, water and chemical admixtures, reinforced randomly distributed fibres. ECC material can improve tensile strength, ultimate strain capacity and large strain hardening properties than conventional concrete. Engineered cementitious composite is called bendable concrete, is an easily mortar based composite reinforced with specially selected short random fibres, usually polymer fibres. The engineered cementitious composite has ductile characteristics, when compared with normal concrete which shows brittle nature. The ECC material also forms high performance fibre cementitious composite family. The ECC is prepared with short random fibres for the effective formation of the fibre matrix as well as to the increase the bond strength. The addition of fibre improves the tensile strength, toughness along with strain capability, and it shows high damage tolerance. These properties significantly the strain hardening behaviour of the material.

Strain hardening is the ability of the material to increase the level of loading after first crack while undergoing large deformation. The addition of polypropylene fibre converts the material in to elastic. The ductility and energy absorbing capacity of the material is increased effectively. The material under loading, load bearing capacity is shows higher than the nominal concrete.

High ductility results of the interaction between cement paste and fibre delayed the crack propagation under higher 
load. The multiple cracks are occurred with many parallel cracks, when the specimen under strain hardening, beyond this limit the localized crack occurred along with fibre bridging. Thus the fibre reduces the width of crack. The ECC can resist large load by the crack bridging properties in the failure mode of structure. This material is also used for the repairing and maintenance work also.

\subsection{FIBRE REINFORCED CONCRETE}

Advanced cement based materials and improved concrete construction techniques provide opportunities for the design of structures to resist severe loads resulting from earthquakes, impact, fatigue, and blast environments. Conventional concrete cracks easily. Brittle nature of concrete which limits the application of the material, can be overcome by the inclusion of a small amount of short randomly distributed fibres (steel, glass, synthetic and natural) and can be practiced among others that remedy weaknesses of concrete, such as low resistance, high shrinkage and cavitation resistance, low durability, etc. Fibre Reinforced Concrete is a concrete mix that contains short, discrete fibres that are uniformly distributed and randomly oriented. The main function of the fibres in members is that of resisting the opening of the cracks due to micro cracking, increasing the ability of the member to with stand the loads.

The characteristic of fibre reinforced concrete are changed by the alteration of quantities of concrete, fibre substances, geometric configuration, dispersal, direction and concentration. It is a special type of concrete in which cement based matrix is reinforced with ordered or random distribution of fibre. The addition of fibres to the conventional concrete is varying from $1 \%$ to $2 \%$ by volume depending on geometry of fibres and type of application. nature, due to this failure happens suddenly and crack development and propagation in the cement paste interface is very easy, also the crack width is very large. In the case of ECC, the short fibres are added. The steel fibre increase the strength and toughness of the material at the same time the addition of polypropylene fibre increase the strain hardening, energy absorption. The cracks development under loading is very small, thus it improves the damage tolerance. The cementitious composite act as a ductile material.

\subsection{METHODOLOGY}

1. Litereture Review

2. Material Collection

3. Mix design

4. Casting of specimen

5. Testing of Specimen

6. Optimum Result

7. Casting of RC beam

8. Testing of RC beam

9. Result \& Discussion

10. Conclusion

\subsection{PROPERTIES OF MATERIALS}

\subsubsection{CEMENT}

The ordinary Portland cement (OPC) of 53 Grade was used for the production of the cementitious composite. Standard consistency and specific gravity were found. The properties of the cement is shown in the following Table 3.1

Table 3.1 Properties of cement

\begin{tabular}{|c|c|c|}
\hline S. No & Property & Results \\
\hline 1 & Fineness & $5 \%$ \\
\hline 2 & Initial setting time & 30 minutes \\
\hline 3 & Specific gravity & 3.15 \\
\hline 4 & Standard consistency & $31 \%$ \\
\hline
\end{tabular}

\subsubsection{FINE AGGREGATE}

The fine aggregate used in this investigation is natural sand and it has a specific gravity of around 2.65. The fineness modulus of sand is taken as $1.18 \mathrm{~mm}$ passed sieve. The properties of the fine aggregate is shown in the following Table 3.

Table 3.2 Properties of fine aggregate

\begin{tabular}{|c|c|c|}
\hline S. No & Property & Results \\
\hline 1 & Specific gravity & 2.65 \\
\hline 2 & Bulking of sand & $20 \%$ \\
\hline 3 & Fineness modulus & 2.78 \\
\hline 4 & Voids ratio & 0.21 \\
\hline
\end{tabular}

\subsubsection{COARSE AGGREGATE}

Coarse aggregate of maximum size of $20 \mathrm{~mm}$ to be used in concrete which has been specified in the codal provisions.

Table 3.3 Properties of coarse aggregate

\begin{tabular}{|c|c|c|}
\hline S. No & Property & Results \\
\hline 1 & Specific gravity & 2.65 \\
\hline 2 & Water absorption & $0.5 \%$ \\
\hline 3 & Fineness modulus & 6.42 \\
\hline 4 & Crushing strength & $2.57 \mathrm{~N} / \mathrm{mm}^{2}$ \\
\hline 5 & Impact value & $7.2 \%$ \\
\hline 6 & Abrasion value & $4.05 \%$ \\
\hline
\end{tabular}




\subsubsection{SILICA FUME}

It has white colour in the powder appearance, it gives high sulphate resistance, corrosion resistance and high strength. The micro silica of $5 \%$ weight of cement is used for the production composite. Silica fume can reduce the pores in the composite. Thus its density is increased also it produce $\mathrm{C}-\mathrm{S}-\mathrm{H}$ gel at the time of hydration process. It helps to achieve better strength.

Table 3.4 Properties of silica fume

\begin{tabular}{|c|l|c|}
\hline S. No & \multicolumn{1}{|c|}{ Property } & Results \\
\hline 1 & Colour & Whitish powder \\
\hline 2 & Physical Properties & Silica fume \\
\hline 3 & Average diameter & 0.5 \\
\hline 4 & $\begin{array}{l}\text { Specific surface area } \\
\left(\mathrm{m}^{2} / \mathrm{Kg}\right)\end{array}$ & 22500 \\
\hline 5 & ${\mathrm{Density}\left(\mathrm{g} / \mathrm{cm}^{2}\right)}^{2}$ & 2.65 \\
\hline 6 & $\mathrm{SiO}_{2}$ & $>95$ \\
\hline 7 & $\mathrm{Al}_{2} \mathrm{O}_{3}$ & $<5$ \\
\hline
\end{tabular}

\subsubsection{STEEL FIBRE}

The steel fiber of $0.45 \mathrm{~mm}$ diameter along with length of 12.5 $\mathrm{mm}$ is used for the production of composite which gives multidirectional reinforcement detailing. It increase crack resistance, ductility, and energy absorption of the composite. Also it provides better the impact resistance and fatigue resistance to composite. Figure 3.1 shows the steel fiber used in the production of composite.

\subsubsection{POLYPROPYLENE FIBRE}

The polypropylene fiber of $18 \mu \mathrm{m}$ diameter along with a length of $12 \mathrm{~mm}$ is used for the production of cementitious composite. It improves the impact resistance, shatter and abrasion resistance. Increase residual strength and durability. Figure 3.2 shows the polypropylene fiber used in the production of composite. The properties of the steel fiber and polypropylene fiber shown in the Table 3.5.

Table 3.5 Properties of fiber

\begin{tabular}{|c|c|c|c|c|c|}
\hline $\begin{array}{c}\text { Fiber } \\
\text { Type }\end{array}$ & $\begin{array}{c}\text { Diameter } \\
(\mu \mathrm{m})\end{array}$ & $\begin{array}{c}\text { Length } \\
(\mathrm{mm})\end{array}$ & $\begin{array}{c}\text { Tensile } \\
\text { strength } \\
(\mathrm{MPa})\end{array}$ & $\begin{array}{c}\text { Density } \\
\left(\mathrm{Kg} / \mathrm{m}^{3}\right)\end{array}$ & $\begin{array}{c}\text { Aspec } \\
\mathbf{t} \\
\text { Ratio }\end{array}$ \\
\hline Steel & 450 & 12.5 & 1100 & 7850 & 65 \\
\hline $\begin{array}{c}\text { Polypro } \\
\text { pylene }\end{array}$ & 20 & 12 & 300 & 946 & 100 \\
\hline
\end{tabular}

\subsubsection{WATER}

Fresh and clean water was for casting and curing of specimens. The water was relatively free from organic matters, silt, oil, sugar, chloride and acidic material as per requirements of Indian Standard.

\subsection{PROPOTIONS}

The mix proportions for the cementitious composite was possessed with 1:3 ratio of cement with sand of $1.18 \mathrm{~mm}$ sieved. The w/c ratio was taken as 0.45 as constant. Short crimpled steel fibre content varies from $0.9 \%-1.2 \%$ with increment of 0.1 . and the polypropylene fibre content varies from $0.09 \%-0.12 \%$ with increment of 0.01 . Silica fume was added in the mix with $5 \%$ weight of the cement.

The concrete mix design was possessed by which the proportions of raw materials of concrete were determined with an aim to achieve minimum strength and durability. The mix proportion used for the study was grade $\mathrm{M}_{20}$ concrete. The Table 3.6 shows the mix ratio of ECC.
Table 3.6 Mix ratio of ECC

\begin{tabular}{|c|c|c|c|c|}
\hline $\begin{array}{c}\text { w/c } \\
\text { ratio }\end{array}$ & $\begin{array}{c}c / s \\
\text { ratio }\end{array}$ & $\begin{array}{c}\text { Silica } \\
\text { fume }\end{array}$ & $\begin{array}{c}\text { Steel } \\
\text { fibre }\end{array}$ & $\begin{array}{c}\text { PP } \\
\text { fibre }\end{array}$ \\
\hline 0.45 & $1: 3$ & $5 \%(w t)$ & $0.9-1.2 \%$ & $0.09-0.12 \%$ \\
\hline
\end{tabular}

\subsection{REINFORCEMENT DETAILS}

The area of reinforcement was provided in the beam as balanced section. All beams were $1100 \mathrm{~mm}$ long, $100 \mathrm{~mm}$ wide and $150 \mathrm{~mm}$ deep. Provided 2 numbers of $10 \mathrm{~mm}$ diameter bar in the tension zone. 10 number of $8 \mathrm{~mm}$ diameter stirrups with spacing of $100 \mathrm{~mm} \mathrm{c} / \mathrm{c} 1 / 3^{\text {rd }}$ distance from both supports and $150 \mathrm{~mm}$ spacing at intermediate distance. The reinforcement details for the beam is shown in Figure 3.3.

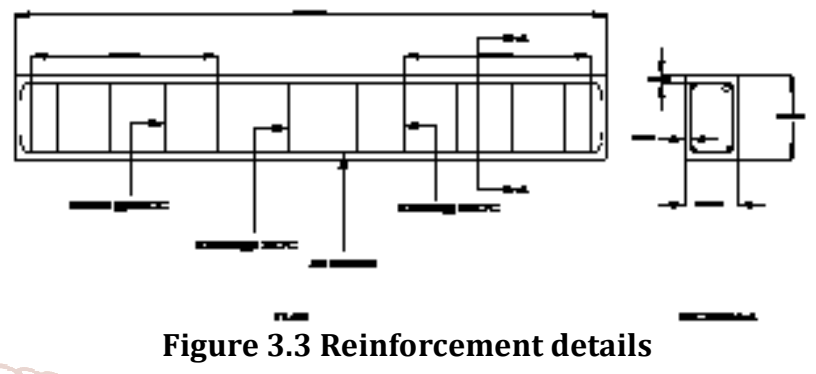

\section{EXPERIMENTAL PROGRAMME}

4.1 GENERAL

The main objective of the experimental work was to study the strength characteristics of cementitious composite material. The main parameters that were studied include compressive strength, displacement, and flexural behaviour under loading. In current scenario cementitious composite is used in the field as construction material as well as a repairing material.

The researchers are performing various experiments on cementitious composite to develop a good durable construction material. Few researchers have been found that the cementitious composite can be used as repairing material for maintenance of dams and bridges.

This study mainly focuses on the compressive strength, strength of RCC beam with cementitious composite. In this study 1:3 mix ratio and $\mathrm{M}_{20}$ grade concrete was used, fine aggregate conforming zone II as per IS code 383-1970 and coarse aggregate passes through $4.75 \mathrm{~mm}$ sieve was used. For making cementitious composite ordinary Portland cement of grade 53 was used.

\subsection{PREPARATIONS OF SPECIMEN}

\subsubsection{Batching}

The measurement of materials for making mortar is known as batching. Here, we have adopted weigh-batching method, and it is the correct method too. Use of weigh system in batching, facilitates accuracy, flexibility and simplicity.

\subsubsection{Preparation of the Mould}

The moulds used for testing were cube, coupon, which were made up of ply wood and the inside faces were machined plane. All the faces of the mould were assembled by using nuts and bolts and are clamped to the base plate. All the internal angle of the mould must be $90^{\circ}$. The faces must be thinly coated with mould oil to prevent leakage during filling. The inside of the mould must also be oiled to prevent the mortar from sticking to it. The Table 4.1 illustrates the size of the specimen. 
International Journal of Trend in Scientific Research and Development (IJTSRD) @ www.ijtsrd.com eISSN: 2456-6470

Table 4.1 size of specimens

\begin{tabular}{|c|c|}
\hline Type of Mould & Size(in mm) \\
\hline Cube & $70.6 \times 70.6 \times 70.6$ \\
\hline Beam & $1100 \times 100 \times 150$ \\
\hline
\end{tabular}

\subsubsection{Mixing}

Thorough mixing of materials is essential for the production of uniform course. The mixing should ensure that the mass becomes homogeneous, uniform in color and consistency. In this project, hand mixing is adopted. As the mixing cannot be thorough, it is desirable to add $10 \%$ more materials.

\subsubsection{Pouring of Mortar}

After mixing, the moulds are filled immediately by pouring the mortar inside the mould. Mortar is filled in three layers, and each layer is compacted well by using a tamping rod of standard size, so as to avoid entrapped air inside the mortar cubes and honey combing effect on the sides. During pouring of mortar, it is better to avoid wasting of mortar for effective and economical usage. In order to avoid wastage, small trowels are used to collect the mortar that is coming out the mould while pouring, and it is again used in the process.

\subsubsection{Compaction of Mortar}

Compaction of mortar is the process adopted for expelling the entrapped air from the mortar. In the process of mixing, transporting and placing of mortar, air is likely to get entrapped in the mortar. The lower the workability, higher is the amount of air entrapped. Hand compaction by using a tamping rod.

\subsubsection{Demoulding}

Test cube specimens are demoulded after 24 hours from the process of moulding. If the mortar has notachieved sufficient strength to enable demouldingwithout damaging the cube specimens, then the process must be delayed for another 24 hours. Care should be taken not to damage the specimen during the process because, if any damage is caused, the strength of the mortar may get reduced.

\subsubsection{Curing}

The test specimens after compaction were kept as such for a period of 24 hours. After that period of time the moulds were removed and the specimens were kept in ordinary curing tank and allowed to cure for a period of 7 and 28 days

\subsection{DETERMINATION OF STRENGTH}

\subsubsection{Compressive Strength}

The cubes were prepared in $70.6 \mathrm{~mm} \times 70.6 \mathrm{~mm} \times 70.6 \mathrm{~mm}$ size moulds and properly compacted. Specimens were demoulded from mould after 24 hours and in water for curing for 7 days and 28 days. Four hybrid fiber combinations were taken in account along with control specimen. After curing, the samples were measured for 7 days and 28 days compressive strength.

\subsubsection{Flexural strength}

The cementitious composite layer was applied on the concrete beam with $20 \mathrm{~mm}$ thickness. After 28 days curing, the specimen was tested by using UTM. The flexural behaviour of the concrete beam without ECC layer was tested and compared the effect of the ECC under flexural loading. The Figure 5.4 shows the flexural loading of control specimen and the Figure 5.5 shows the flexural loading of hybrid specimen. The failure modes of the control and hybrid specimens are shown in the Figure 4.6.

\section{RESULTS AND DISCUSSION \\ 5.1 COMPRESSIVE STRENGTH}

The Table 5.1 shows average results of compressive strength of cubes with steel fiber at 28 days.

Table5.1 Compressive strength of cubes with steel fiber

\begin{tabular}{|c|c|c|}
\hline SI. No & $\begin{array}{c}\text { Steel fibre content } \\
\text { (in volume } \\
\text { percentage) }\end{array}$ & $\begin{array}{c}\text { Compressive } \\
\text { strength at } 28 \text { days } \\
\left(\mathrm{N} / \mathbf{m m}^{2} \text { ) }\right.\end{array}$ \\
\hline 1 & 0 & 12 \\
\hline 2 & 0.5 & 19.10 \\
\hline 3 & 1.0 & 20.08 \\
\hline 4 & 1.5 & 16.62 \\
\hline 5 & 2.0 & 15.50 \\
\hline
\end{tabular}

The compressive strength results showed that the $1.0 \%$ steel fiber content composite gives ultimate strength. The Figure 5.1 given below represents the compressive strength for steel fiber at 28 days.

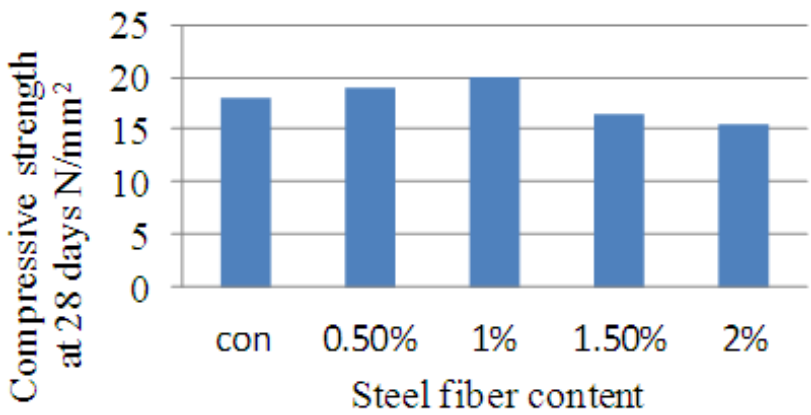

Figure5.1Compressive strength of cubes with steel fiber

The Table 5.2 shows average results of compressive strength of cubes with polypropylene fiber at 28 days.

Table 5.2 Compressive strength of cubes with polypropylene fiber

\begin{tabular}{|c|c|c|}
\hline SI. No & $\begin{array}{c}\text { Polypropylene } \\
\text { fiber (in volume } \\
\text { percentage) }\end{array}$ & $\begin{array}{c}\text { Compressive } \\
\text { strength at 28 days } \\
\left(\mathbf{N} / \mathbf{m m}^{2} \text { ) }\right.\end{array}$ \\
\hline 1 & 0 & 12 \\
\hline 2 & 0.10 & 19.07 \\
\hline 3 & 0.15 & 10.50 \\
\hline 4 & 0.20 & 15.08 \\
\hline 5 & 0.25 & 14.02 \\
\hline
\end{tabular}

The compressive strength results showed that the $0.10 \%$ polypropylene fiber content composite gives ultimate strength. The Figure 5.2 given below represents the compressive strength value of polypropylene fiber at 28 days.

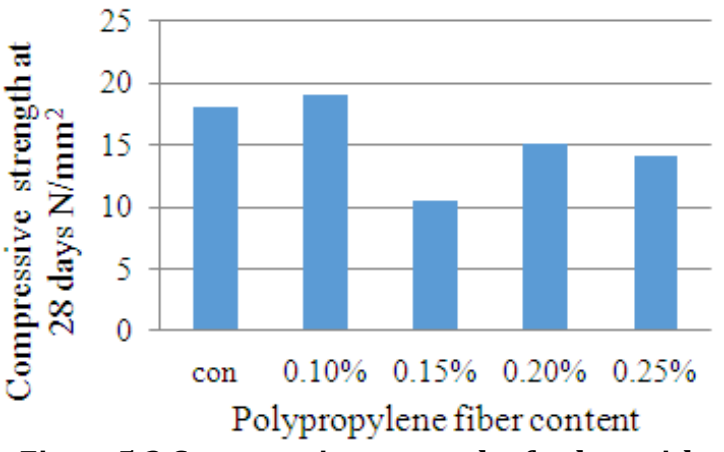

Figure5.2 Compressive strength of cubes with polypropylene fiber 
The Table 5.3 shows average results of compressive strength of cubes with hybrid steel- polypropylene fiber at 28 days.

Table 5.3 Compressive strength of cubes with hybrid steel-polypropylene fiber

\begin{tabular}{|c|c|c|}
\hline $\begin{array}{c}\text { Sl. } \\
\text { No }\end{array}$ & $\begin{array}{c}\text { Hybrid } \\
\text { fiber }\end{array}$ & $\begin{array}{c}\text { Compressive strength at } \\
\text { 28 days }\left(\mathbf{N} / \mathbf{m m}^{2}\right)\end{array}$ \\
\hline 1 & Control & 18.08 \\
\hline 2 & $\mathrm{H}_{1}$ & 20.10 \\
\hline 3 & $\mathrm{H}_{2}$ & 26.62 \\
\hline 4 & $\mathrm{H}_{3}$ & 34.67 \\
\hline 5 & $\mathrm{H}_{4}$ & 39.18 \\
\hline
\end{tabular}

The compressive strength results showed that the hybrid steel- polypropylene fiber content $(1.2 \%$ steel fiber and 0.12 polypropylene fibers) composite showed ultimate strength of $39.12 \mathrm{~N} / \mathrm{mm}^{2}$. The Figure 5.3 given below represents compressive strength at 28 days.

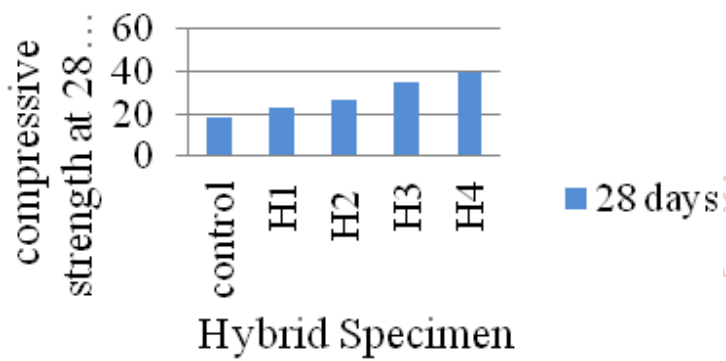

Figure5.3 Compressive strength of cubes with hybrid steel-polypropylene fiber

\subsection{SEM ANALYSIS}

Scanning electron microscopic analysis was conducted for the control specimen and hybrid specimen. The results show that the pores and voids in the composite is very less due to the addition of silica fume. The strength of the control specimen achieved at 28 days is very low when compare to hybrid composite. Whereas the strength of hybrid fiber achieved at 28 days is $39 \mathrm{~N} / \mathrm{mm}^{2}$. The reason for the achievement is the effective distribution of the fibers. It giveseffect the multi-directional reinforcement. The addition of synthetic fibers gives more energy absorption capacity, it results large load bearing and it behave like ductile material. The images for the conventional and hybrid fiber composite are shown in Figure 5.4 and 5.5. In the case conventional specimen, the surface voids are more than that of hybrid fiber sample. The addition of silica fume reduced the surface voids in the sample. The fibers are almost equally distributed which is act as a multidirectional reinforced system. The fiber bonding is very good in sample. The separation of the particle is very small in the sample. The super plasticizer counteract for the strengthattaining of sample.
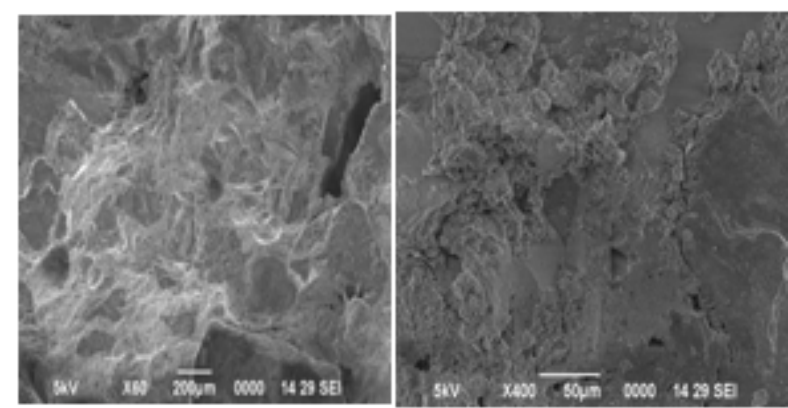

Figure 5.4 Surface structure of conventional cube

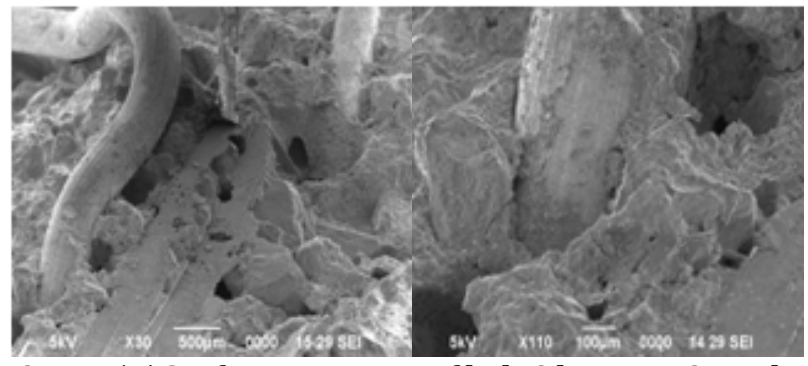

Figure 5.5 Surface structure of hybrid composite cube

\subsection{ENERGY ABSORPTION}

The Table 5.4 shows the energy absorption of the specimen under flexural loading condition.

Table 5.4 Energy absorption of the specimen

\begin{tabular}{|c|c|c|}
\hline SI. No & Specimen & Energy absorption (Nmm) \\
\hline 1 & Control & 138.40 \\
\hline 2 & $\mathrm{H}_{1}$ & 244.52 \\
\hline 3 & $\mathrm{H}_{2}$ & 401.48 \\
\hline 4 & $\mathrm{H}_{3}$ & 260.60 \\
\hline 5 & $\mathrm{H}_{4}$ & 190.42 \\
\hline
\end{tabular}

The energy stored in the conventional beam under loading is $138.44 \times 10^{3} \mathrm{Nmm}$. The energy absorption capacity of the specimen increased $1.9 \%$ than the control specimen when compared with hybrid composite. The result shows that the energy absorption capacity increased with increasing fiber content. The graph shows the energy levels in the specimens under loading condition.

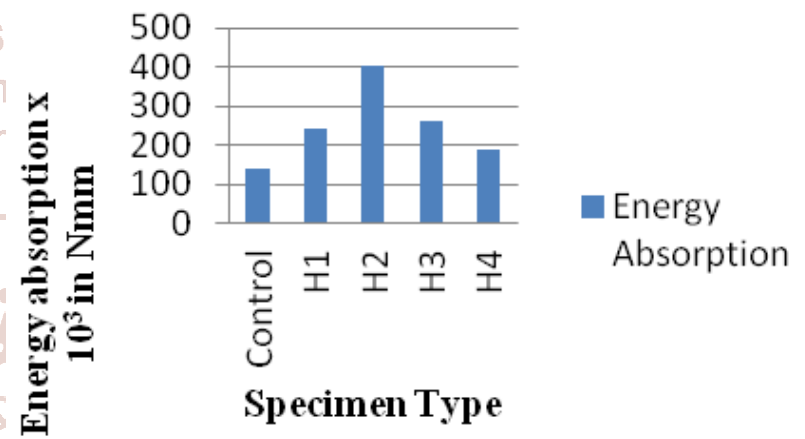

Figure 5.6 Energy absorption of the specimen

\subsection{STIFFNESS}

The Table 5.5 shows the stiffness results of the specimen under third point loading condition.

Table 5.5 Stiffness of the specimen

\begin{tabular}{|c|c|c|}
\hline Sl. No & Specimen & Stiffness $(\mathrm{N} / \mathbf{m m})$ \\
\hline 1 & Control & 2.28 \\
\hline 2 & $\mathrm{H}_{1}$ & 7.09 \\
\hline 3 & $\mathrm{H}_{2}$ & 10.56 \\
\hline 4 & $\mathrm{H}_{3}$ & 4.21 \\
\hline 5 & $\mathrm{H}_{4}$ & 13.23 \\
\hline
\end{tabular}

The stiffness is the load required to produce unit displacement. The stiffness of the control specimen is 2.24 $\mathrm{N} / \mathrm{mm}$. The stiffness of the specimen is increased $4.95 \%$ in the hybrid cementitious composite beam. The stiffness is increased $3.8 \%$ in the hybrid composite beam. The Figure 5.7 given below represents the stiffness value of the beam. 


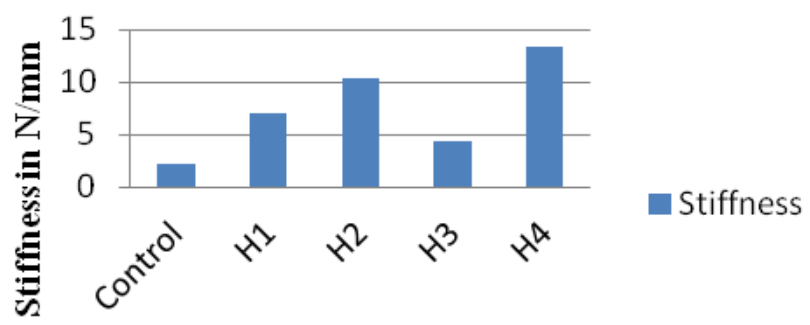

Specimen Type

Figure 6.7 Stiffness of the specimen

\subsection{DUCTILITY FACTOR}

The Table 5.6 shows the ductility factor of the specimen under third point loading.

Table 5.6 Ductility factor of the specimen

\begin{tabular}{|c|c|c|}
\hline Sl. No & Specimen & Ductility factor \\
\hline 1 & Control & 2.74 \\
\hline 2 & $\mathrm{H}_{1}$ & 3.45 \\
\hline 3 & $\mathrm{H}_{2}$ & 4.27 \\
\hline 4 & $\mathrm{H}_{3}$ & 3.32 \\
\hline 5 & $\mathrm{H}_{4}$ & 3.50 \\
\hline
\end{tabular}

The ductility is the ability of the material to width stand large load under deformation without failure. The ductility factor is the ratio between deformations at the first crack load to deformation at the ultimate load. The ductility factor of the control specimen is 2.75. The maximum ductility factor shown by hybrid $\mathrm{H}_{2}$ specimen. The ductility factor increased $5.0 \%$. The load carrying capacity of the specimen is increased. The polypropylene fiber content increased the ductility of the specimen. The Figure 5.8 below represents the ductility factor variation in each specimen.

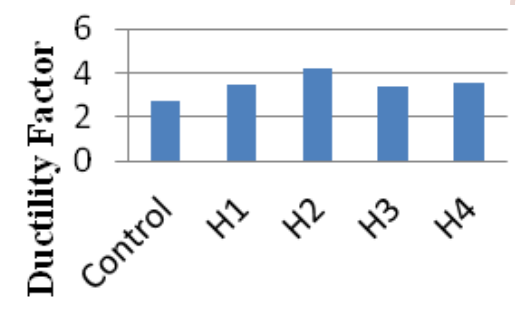

Specimen Type

Figure 5.8 Ductility factor of the specimen

\subsection{LOAD Vs. DEFLECTION CURVE}

The load Vs deflection curve is represented in the following Figure 5.9. The load carrying capacity of the hybrid beams are increased due to the application of the composite on the beam. The maximum capacity is obtained on at hybrid specimen which carrying $1 \%$ of steel fiber and $0.1 \%$ of polypropylene fiber.

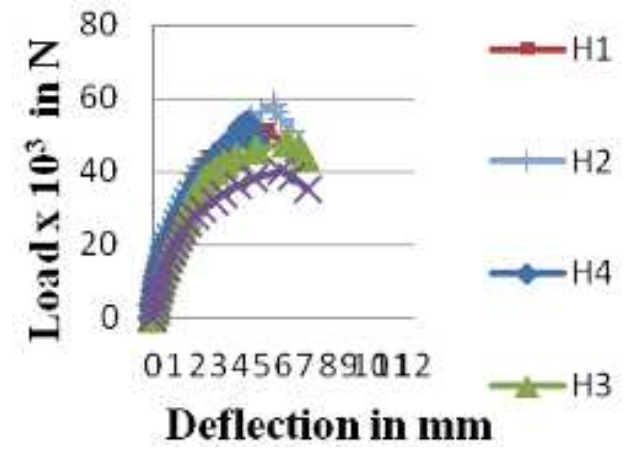

Figure 5.9 Load vs. Deflection behaviour of beams

\section{CONCLUSION}

From the literature review and experimental work, the following conclusions were obtained. The silica fume is increased the strength of the cementitious composite. The contribution of the fibers increased the strength; the polypropylene fiber increased the ductility of the material.

$>$ The study concluded that the compressive strength of the cementitious composite improved $1.2 \%$ than the control specimen, the silica content in cementitious composite increased the strength and fibers counteract with strength and ductility.

$>$ The energy absorption capacity of the material is increased $1.9 \%$ than the control specimen. The fibers are acting as a multi directional reinforcement. The energy absorption capacity is mainly due to the polypropylene fiber content.

$>$ The voids on the samples are very small and very less when compared with control specimen. The voids are reduced by the addition of silica fume due to fineness of it, also the bond strength between the fibers to binding material is very strong in samples.

$>$ The stiffness is the load required to produce unit displacement. The stiffness of the samples is increased due to the fiber content. The stiffness of the samples improved $4.95 \%$ than control specimen.

$>$ The ductility is the ability of the material to withstand large load with small deformation without failure. The ductility is mainly provided by polypropylene fiber. The ductility factor is improved $5.0 \%$ of the control specimen.

The first crack load is increased in the samples due to the fiber content as well as multiple cracks developed due to the bridging effect of the fiber. It increased the load carrying capacity with reducing the crack width. Beyond the limit any of the crack is widening and slowly failure is occurred.

$>$ From the load vs. deflection curve, the load capacity is very large obtain at steel fiber content of $1 \%$ and polypropylene fiber of $0.1 \%$. The compressive strength of the cementitious composite is also increased.

\section{REFERENCES}

[1] Ahmed S.F.U, Maallej M (2009), "Tensile strain hardening behaviour of hybrid steel-polypropylene fiber reinforced cementitious composites", Construction and building materials, Vol.23, pp 96-106.

[2] AhmetCavdar (2012), "A study on the effects of high temperature on mechanical properties of fiber reinforced cementitious composites", Vol.43, pp 24522463.

[3] KamileTosun, Burak (2013), "Effects of fiber hybridization on multiple cracking potential of cement based composites under flexural loading", Construction and building materials, Vol.41, pp 15-20.

[4] Karihaloo B L (2000), "Mechanics of fiber-reinforced cementitious composites", Computers and structures, Vol.76, pp 19-24.

[5] Khin T Soe, Zhang YX (2013), "Material properties of a new hybrid fiber-reinforced engineered cementitious composite", Construction and concrete materials, Vol. 43, pp 399-407. 
International Journal of Trend in Scientific Research and Development (IJTSRD) @ www.ijtsrd.com eISSN: 2456-6470

[6] Mohammed Ezziane (2011), "Heat exposure tests on various types of fiber mortar", Vol.15, pp 715-726.

[7] PitiSukontasukkul (2003), "Tensile behaviour of high content steel and polypropylene fiber reinforced mortar", Vol.8, pp 50-56.
[8] PitiSukontasukkul (2004), "Fracture of high content polypropylene fiber reinforced cement mortar under direct tensile loading", Vol.14.

[9] Sheikh FaizUddin Ahmed (2007), "A review on durability properties of strain hardening fiber reinforced cementitious composites", Cement and concrete composites, Vol.29, pp365-376. 